"This is the peer reviewed version of the following article Do Sovereign Re-Ratings Destabilize Equity Markets during Financial Crises? New Evidence from Higher Return Moments

Journal of Business Finance \& Accounting, 42(5) \& (6), 777-799, June/July 2015, 0306-686X which has been published in final form at doi: $10.1111 / \mathrm{jbfa} .12119$ This article may be used for non-commercial purposes in accordance with Wiley Terms and Conditions for Self-Archiving." 


\title{
Do sovereign re-ratings destabilize equity markets during financial crises?: New evidence from higher return moments
}

\author{
Robert Brooks \\ Department of Econometrics and Statistics, Monash University, Clayton, VIC, \\ Australia \\ Robert Faff \\ UQ Business School, The University of Queensland, QLD, Australia \\ Sirimon Treepongkaruna \\ UWA Business School, University of Western Australia, Australia \\ Eliza $\mathrm{Wu}^{\#}$ \\ University of Technology Sydney, UTS Business School, Ultimo, NSW 2007, \\ Australia
}

\begin{abstract}
We investigate the effects of S\&P's sovereign re-ratings on the higher moments of equity market returns over recent financial crises. Using a set of intraday stock market index prices and sovereign credit ratings for a sample of 36 countries which experienced sovereign rating changes over the period from 1996 - 2013, we find that the higher moments of stock market returns are significantly more responsive to sovereign re-ratings during financial crises but the effects on stock markets are not the same across different financial crises. The effects during crises are however magnified for large downgrades and those that are associated with a loss of investment grade status. We find that there are asymmetric effects during financial crises in that downgrades are consistently more significant than upgrades in increasing realized volatility and realized kurtosis. Both upgrades and downgrades affect realized skewness in times of crises in the expected direction.

JEL: G15, F30, F31

Keywords: sovereign ratings, realized volatility, realized skewness, realized kurtosis, stock market impact
\end{abstract}




\section{Introduction}

Credit rating agencies are known as specialist financial information intermediaries and serve to facilitate the efficient operation of financial markets. Yet, the informational value of credit ratings and the impact of rating agencies in the international financial system continues to be widely debated, particularly their procyclical role in amplifying financial crises (see, for example, Kaminsky and Schmukler (1999), Michaelides et al. (2014) and Reisen and von Maltzan (1999)).

The recent spate of downgrades given by credit rating agencies over the period from 2011-2013 to advanced countries like the UK, France, Spain and Italy alongside the troubled sovereigns like Greece, Portugal and Cyprus during the European Sovereign Debt Crisis motivates a need to address whether rating agencies' actions in times of financial crises are potentially destabilizing for financial market activity. The International Monetary Fund (2010) has stressed that sovereign credit risk is one of the main current threats to global economic stability.

It has been documented in the recent literature that there are significant effects on firm performance within a country when the country's sovereign credit ratings have been revised. For instance, Cumming, Hou and Wu (2014) show that sovereign governance (as proxied by sovereign credit ratings) is an important determinant of firm value and affects firm performance distinctly over and above the more traditional aspects of firm-level corporate governance. More recently, Hill, BissoondoyalBheenick and Faff (2014) and Bedendo and Colla (2013) have shown that there is a strong dependence between sovereign and firm credit risk within a country. As such, it is important to understand how changes in sovereign governance captured by sovereign credit rating revisions can affect all firms' stock performance in aggregate within a country. However, our work deviates from prior studies that have focused 
exclusively on assessing the market impact of sovereign credit ratings on stock returns and volatility by focusing on the effects of rating activity on the higher moments of stock returns over different types of financial crises.

There is an extensive literature linking the information content of sovereign credit ratings and stock market activity (see Brooks et al., 2004, Ferreira and Gama, 2007 and Hill and Faff, 2010 amongst others). There are two potential channels through which sovereign credit ratings would affect the stock market. First, sovereign credit ratings reflect the perceived future macroeconomic strength and fiscal soundness of a country. Hence, as these credit assessments deteriorate it is more likely that national governments will look to increase corporate taxes levied on firms in that country and this should be reflected in aggregate stock market performance. Second, sovereign credit ratings are understood to provide a 'debt ceiling' for all corporate debt issued from a given country suggesting that as sovereign credit ratings are revised then the cost of and even the access to debt for firms is also affected and this should also be reflected in firms' stock prices. Consistent with this view, Almeida et al. (2014) show that due to the sovereign ceiling effect, firms with credit ratings on parity or above their country's sovereign credit ratings are affected to a greater extent by sovereign rating downgrades. When the sovereign gets downgraded, these firms are forced to cut back on corporate investments as their borrowing costs increase from rating agencies' flow-on adjustments to their corporate credit ratings.

The main objective of our paper is to investigate the market impact of sovereign rating changes over several recent major episodes of financial crises for a global sample of countries. We employ a matched panel data method to fully capture a country's own rating impacts and we use intraday stock market data within a trading week to compute the second, third and fourth realized moment of stock market 
returns. We ask four related questions: 1) Do sovereign re-ratings have a greater impact on higher moments during times of financial crises? 2) Are there asymmetric impacts on higher moments with downgrades being more significant than upgrades? 3) Does the nature of the re-rating matter in terms of size and investment grade status? 4) Are sovereign re-ratings more significant in debt crises?

Focusing on the higher moments of realized return distributions is critical to fully understanding the potentially destabilizing effects of sovereign credit assessments within equity markets, especially during times of financial turmoil when the fat-tailed nature of stock returns become more prominent. Yet, there has been little attention placed on the impact of credit ratings on the higher moments of asset return distributions. The transmission of information contained in sovereign ratings can conceivably extend to affect the dynamics of higher moments such as variance, skewness and kurtosis. The shape of return distributions dictated by their higher moments are known to influence financial decision making and studies like Hong and Stein (2003) show, for example, that skewness is related to information dispersion within financial markets. Other studies such as Harvey and Siddique (2000), Brunnermeier and Pedersen (2009) and Albuquerque (2012) document the importance of the third and fourth moments of equity returns and their predictability for stock returns. Brunnermeier and Pedersen (2009) also highlighted that funding constraints can lead to high volatility and kurtosis as well as negatively skewed returns in equity markets. When sovereign credit ratings are downgraded, the cost of financing for firms increase via the sovereign ceiling mechanism and this is likely to affect the higher moments of stock returns.

We find evidence that rating events become more significant in affecting the higher moments of returns during financial crises suggesting that rating agency 
decisions do contribute to greater financial market instability in times of crises. We find there are also asymmetric impacts of sovereign re-ratings on higher moments and that large multi-notch downgrades and those resulting in loss of a country's investment grade status are particularly destabilizing for equity markets. We also find evidence to indicate that equity markets are more sensitive to sovereign re-ratings during debt-related crises.

Our findings have real implications for financial market participants. A clearer understanding of sovereign rating impacts during financial crises is important for users of credit ratings like equity analysts, financial risk managers and policy makers in dealing with recurring financial crises and financial market instability.

The organization of this paper is as follows. In Section 2, we provide a description of data and sampling, followed by empirical modelling in Section 3. In Section 4 we discuss our findings before concluding in Section 5.

\section{Literature Review}

There is an extensive literature documenting the stock market impacts of sovereign credit ratings and its spillover effects internationally. Whilst the impacts on other financial markets have also been studied, we focus only on reviewing the stock market impact literature as our study is the most closely aligned with this body of work.

Kaminsky and Schmukler (1999) document that during the 1997-98 Asian Financial Crisis daily stock price movements were heavily influenced by credit rating agencies' news on countries within the region and that stock market participants overreacted to such news. 
Brooks et al. (2004) investigate the impact of sovereign credit ratings on national equity markets over the sample period from 1 January 1973 to 31 July 2001 and show that rating downgrades in particular have negative impacts on domestic stock market returns. Taking an event study approach, they find 1-day abnormal returns of -197 basis points in reaction to a one-notch drop in the country's own sovereign credit ratings. Of the major rating agencies examined, they reveal that Standard and Poor's exerts the greatest stock market impact.

Kaminsky and Schmukler (2002) also examine the impact of sovereign credit ratings activity across various financial crises during the second half of the 1990s. However, they do not differentiate between the size of sovereign credit re-ratings as they only test the significance of indicator variables that take on non-zero values for any change in sovereign credit ratings or outlooks. They find that stock markets are affected more by sovereign rating activity during financial crises and that crosscountry spillover effects are only significant during crisis periods consistent with the development of financial contagion.

Hill and Faff (2010) contribute further evidence on sovereign credit rating actions during financial crises. They extend upon the initial work of Kaminsky and Schmukler (2002) and examine a larger number of financial crises up to the early 2000s. They also find that the information content of sovereign credit ratings activity is stronger during financial crises relative to non-crisis periods. However, they only assess the market impact of sovereign credit ratings based on cumulative stock market returns. In a related vein, Fei, Fuertes and Kalotychou (2012) examine credit rating migration over the business cycle and show that rating downgrades are concentrated in periods of economic contractions. Overall, these studies suggest that rating activity may potentially destabilize financial markets and exacerbate financial crises. 
Instead of focusing on own-country rating impacts, Ferreira and Gama (2007) also investigate the spillover effects of sovereign credit ratings into international stock markets. Similar to Kaminsky and Schmukler (2007), they also document that rating spillovers were more significant in international equity markets during earlier international financial crises in the 1990s and early 2000s. They use an event study approach and document the cumulative effects on stock market return spreads (return differential vis-à-vis the US) from changes in sovereign credit assessments (rating events) over two-day windows. They find a negative reaction of 51 basis points in non-event countries in response to sovereign credit rating downgrades. Upgrades, however, have no significant impact on return spreads of non-event countries. Furthermore, they show that closeness (e.g., geographic proximity, trade linkages) and emerging market status amplify the effect of a rating spillover.

While the heightened information value of sovereign credit assessments for stock market returns during financial crises is established in the current literature, there has been much less attention placed on the impacts on the higher moments of stock market returns in times of crises. ${ }^{1}$ We aim to fill this void in the literature. To our best knowledge, we are the first to provide comprehensive empirical evidence on the nature of sovereign credit re-ratings and their effects on higher return moments across a complete history of past as well as more recent financial crises. We argue that not all financial crises are the same in terms of causes and effects and a reliable assessment of sovereign re-rating effects requires a broad experiment across several types of financial crises.

\footnotetext{
${ }^{1}$ Recently, Do et al. (2014) document the effects of sovereign rating regimes on higher moments of equity returns for a small sample of European stock markets during the European Debt Crisis. However, they do not examine rating upgrade or downgrade events per se but rather the time periods (or regimes) during which there have been upgrades and downgrades.
} 


\section{Data description}

Our dataset consists of the intraday price levels for representative stock market indices from a sample of 36 countries. The countries in our sample all experienced sovereign credit rating changes over the period from 2 January 1996 to 13 November 2013. The intraday data are tick-by-tick stock market index levels captured from Reuters' trading terminals and provided by SIRCA (Securities Industry Research Centre of Asia) in their Thomson Reuters Tick History database.

In addition, we use the history of long-term sovereign credit ratings on foreign currency denominated debt from Standard and Poors as a country's ability to service debt in foreign hard currencies is what truly matters when sovereign obligors have the option to print money to repay debt denominated in their local currency. ${ }^{2}$ As the timing of ratings announcements are irregular, ${ }^{3}$ we focus on the impact of ratings announcements on realized return-based measures in the week in which a rating change occurs. It has been documented in prior studies like Brooks et al. (2004) and Michaelides et al. (2014) that there are cumulative effects on stock market returns over the few days around a sovereign rating change. ${ }^{4}$ Following the approach of Gande and Parsley (2005) and Ferreira and Gama (2007) (among others), we first transform actual ratings given by S\&P into linear scores and we analyse the influence

\footnotetext{
${ }^{2}$ Previous studies reveal that S\&P rating changes exert the greatest impact on stock market returns and are less anticipated (see, e.g., Reisen and von Maltzan (1999), Brooks et al. (2004) and Hill and Faff (2010)). Furthermore, Alsakka and ap Gwilym (2010) show that Standard and Poors' sovereign credit ratings are the least dependent on other rating agencies actions and Alsakka and ap Gwilym (2012b) reveal that S\&P credit assessments are more accurate. In unreported results, we also find that ratings on local currency denominated debt have much weaker effects on higher moments. These results are available upon request.

${ }^{3}$ While S\&P ratings announcements are generally made a.m. local time, the exact timing varies. Michaelides et al. (2014) also highlight that there exists a period of a few days during which rating agencies consult with the rated entity after the rating decision has been approved but before the public announcement.

${ }^{4}$ Unlike prior studies, we do not directly test the effects of sovereign outlooks and watches provided by rating agencies as these are temporary assessments that are usually changed again or lead to permanent rating changes within a few days and are thus, less meaningful at the weekly frequency. Hence, our results serve to provide a lower bound on the stock market impact of sovereign ratings activity during financial crises.
} 
of rating revisions. We define an actual 'rating event' as a non-zero change in the linearised rating scores. We examine a total of 222 sovereign rating events in our overall sample (comprising 106 upgrades and 116 downgrades). These are summarised in Table 1 and the distribution of sovereign rating revisions by country is summarised in Table 2. In Table 1, both Panels A and B show that 91 per cent of all upgrades and $72 \%$ of all downgrades are adjustments of a single notch. They also report that there are more multi-notch downgrades (28\%) than upgrades (9\%). Table 2 shows that Indonesia is the most actively re-rated country in our sample, having experienced a total of 19 events, closely followed by Argentina and Greece with 16 rating revisions each. Greece however, has experienced the highest incidence of multi-notch re-ratings (3 upgrades, 6 downgrades) followed by Indonesia (3 upgrades, 4 downgrades). These countries have been at the heart of major financial crises in Asian, Latin America and Europe throughout our sample period. Panel D of Table 1 shows that sovereign re-ratings occur primarily for emerging markets (81\% of upgrades and 63\% of downgrades) consistent with Ferreira and Gama’s (2007) earlier finding on more significant rating spillovers to emerging markets.

$<$ Insert Tables $1 \& 2>$

As depicted in Figure 1, credit rating agencies are generally more active in re-rating countries around periods of international financial crises than in non-crisis periods. Table 1 Panel $\mathrm{C}$ also shows that $87 \%$ of downgrades and $64 \%$ of upgrades occur during financial crises.

$<$ Insert Figure 1> 
Based on the work of Andersen and Bollerslev (1998), Barndorff-Nielsen and Shephard (2001) and Andersen et al. (2003), we argue that realized measures calculated based on intraday returns provides more consistent and efficient measures than their counterparts computed from close to close prices. We consider the first four moments of realized returns.

We define weekly realized returns as:

$$
\mathrm{R}_{t}=\sum_{d=1}^{D} r_{d, t}
$$

and the weekly realized volatility as:

$$
\mathrm{RV}_{t}=\sum_{d=1}^{D} r_{d, t}^{2}
$$

where $r_{d, t}$ denotes a $d$ th 5 -minute return ${ }^{5}$ during all trading days in week $t$ and $D$ denotes the total number of 5-minute return intervals over the week in which a rerating takes place. ${ }^{6}$

The weekly realized skewness for any given week $t$ is calculated as:

$$
R S_{t}=\frac{\sqrt{D} \sum_{d=1}^{D} r_{d, t}^{3}}{\left(\sum_{d=1}^{D} r_{d, t}^{2}\right)^{3 / 2}}
$$

and we compute weekly realized kurtosis as:

$$
\mathrm{RK}_{t}=\frac{D \sum_{d=1}^{D} r_{d, t}^{4}}{\left(\sum_{d=1}^{D} r_{d, t}^{2}\right)^{2}}
$$

where $r_{d, t}$ denotes a $d$ th 5 -minute return ${ }^{7}$ during all trading days in week $t$ and $D$ denotes the total number of 5-minute return intervals over the week in which a rerating takes place.

\footnotetext{
${ }^{5}$ The intraday return is calculated as the log difference of the stock market index level at the end and beginning of the $d$ th interval.

${ }^{6}$ Based on volatility signature plots (available upon request), we use the daily realized measures computed from 5 minute intervals for our empirical estimations as they are most stable for this sampling interval. As a robustness check, we also use measures based on alternative lower frequency sampling intervals $(10,15$, and 30 minutes). Our regression results remain qualitatively unchanged.
} 
Table 3 reports the average values of the first four weekly realized moments of stock market return distributions for each of our 36 sample countries. Over the entire sample period studied, we find that Uruguay’s stock market index has provided the lowest return (-0.19 percent on a weekly basis) while both Malta's and Venezuela’s stock market index provides the highest return ( 0.77 percent per week). New Zealand's stock market index exhibits the lowest sample volatility, while Uruguay's stock market index is the most volatile. Consistent with the second moment, there is also a wide variation in the degree of kurtosis across countries ranging from Italy’s 1.128 to 529.35 for Malta. Typically, emerging markets like Brazil, Colombia, Ireland and Malta exhibit the highest kurtosis values indicating that they have extremely fat-tailed return distributions. Most countries have a left-skewed return distribution (with Brazil having the most negative skew of -19.82) but there are also a number of emerging markets with right-skewed return distributions (Malta tops the list at 22.41). These properties are consistent with stylized facts regarding emerging market returns.

\section{$<$ Insert Table 3>}

\section{Empirical modeling}

We examine changes in sovereign credit ratings assigned by S\&P to a sample country's foreign currency denominated sovereign debt. Following the approach of Gande and Parsley (2005) and Ferreira and Gama (2007) (among others), we transform actual ratings into linear scores. We analyse the influence of re-ratings to

\footnotetext{
${ }^{7}$ The intraday return is calculated as the log difference of the stock market index level at the end and beginning of the $d$ th interval.
} 
understand the effects of rating agencies' decisions on the higher moments of stock market returns.

In the spirit of Ferreira and Gama (2007), we construct two balanced panel datasets comprising weekly observations for rating event countries matched with randomly selected non-rating event countries (within our sample of 36 countries) in order to run separate regressions for sovereign rating upgrades and downgrades relative to a benchmark of randomly selected non-event country-weeks. However, unlike Ferreira and Gama (2007) we assess realized moments in the week in which the re-rating occurred rather than in 2 day post-event windows as firstly, this accounts for the information leakage problem recently documented by Michaelides et al. (2014) in the pre-announcement consultation phase for the rated sovereign. Second, we use a cumulative measure of rating changes within a week denoted as notch_w, to control for the intensity and magnitude of re-rating activity in the actual week in which a rating event occurs. Third, the weekly frequency is better suited to accommodating macroeconomic control variables that are based on data available at lower frequencies. Hence, we estimate the following base-line panel regression specification with country fixed effects and clustered standard errors to account for time-invariant omitted variables:

$$
\begin{gathered}
R M_{i, t}=\alpha+\beta_{1} R M_{i, t-1}+\beta_{2} \text { Rating }_{i, t}+\beta_{3} \text { notch }_{-} w_{i, t}+\beta_{4} \text { Crisis }_{t}+\beta_{5} \text { Crisis }_{t} \\
\times \text { notch_w } w_{i, t}+\beta_{6} X_{i, t}+u_{i, t}
\end{gathered}
$$

where $R M_{i, t}$ is the realized moment (volatility $(R V)$, skewness $(R S)$, kurtosis $(R K)$ ) for country $i$ in week $t$; $R M_{i, t-1}$ is the realized moment in the past week; $R A T I N G$ is the average level of country i's linearized sovereign credit rating score during week $t$; notch_w are the cumulative weekly rating changes and Crisis is an indicator variable denoting the periods of financial crises (Asian financial crisis - AFC, Russian debt 
crisis - RDC, Technology bust - TECH, the global financial crisis - GFC, European debt crisis - EDC, and ALL aggregates all the individual major and minor financial crises occurring during our sample period). ${ }^{8} \mathrm{X}$ is a matrix of macroeconomic controls which may affect stock market performance. The main variables of interest in our baseline model are notch_w and its interactions with the crisis indicator. The ratings variable (in levels) controls for the relative position of each country on the rating scale i.e. their creditworthiness. It has been highlighted by Ferreira and Gama (2007) that the impact of sovereign credit information is not the same in countries of differing credit quality.

We investigate whether sovereign re-ratings are significant in financial crises even after controlling for some economic determinants that are known to often serve as inputs into agencies' credit rating models (Hill, Brooks and Faff (2010)). We incorporate into the $X$ matrix log GDP (in millions) to proxy the size and performance of a country's economy (Log_GDP); the volatility of the local exchange rate against the US dollar measured as rolling weekly standard deviations of the local currency's returns ( $F X_{-}$vol). Monetary policy is a tight monetary policy regime indicator (Mon_policy) taking a value of 1 from the week when short term interest rates increased until the next interest rate cut at which time it reverts to a value of 0 until the next interest rate hike.

Since there is an extensive list of potential determinants for stock market returns-based measures, we utilise a 'general to specific' model selection approach. For brevity, we only report estimation results for the most parsimonious model with 3

\footnotetext{
${ }^{8}$ The Asian, Russian and Tech financial crises dummy variables are defined to take a value of one in weeks during the relevant financial crisis and zero otherwise, based on dates in Kaminsky and Schmukler (2002) and Kaminsky et al. (2003). The beginning of the European debt crisis on Dec. 2008 is based on the events reported in the Bank for International Settlements' Committee on the Global Financial System's (BIS, 2011) study on sovereign and bank funding risks and the dating of the GFC from Jul. 2007 is based on the Federal Reserve Bank of St Louis' website (https://www.stlouisfed.org/financial-crisis/full-timeline).
} 
key macroeconomic control variables to avoid over-identification in our estimations. We report the model specification which provides the best fit for all realized higher moments assessed across the equity markets studied.

To investigate whether the size of re-ratings matters for the impact of reratings during financial crises we run the model shown in Eq. (6):

$$
\begin{aligned}
R M_{i, t}=\alpha+ & \beta_{1} \\
& R M_{i, t-1}+\beta_{2} \text { Rating }_{i, t}+\beta_{3} \text { single_notch_w } w_{i, t}+\beta_{4} \text { multi_notch_w } w_{i, t} \\
& +\beta_{5} \text { Crisis }_{t}+\beta_{6} \text { Crisis }_{t} \times \text { single_notch_w } w_{i, t}+\beta_{7} \text { Crisis }_{t} \\
& \times \text { multi_notch_w } w_{i, t}+\beta_{8} X_{i, t}+u_{i, t}
\end{aligned}
$$

where the dependent variables represented by $R M_{i, t}$ and the independent variables Rating $_{i, t}$ and Crisist are as defined previously and single_notch_wi,t and multi_notch_wi,t are the sum of all sovereign rating changes of a single notch and of multiple notches, respectively over the trading week in which a rating event occurs.

Next, as many institutional investors are restricted from investing in noninvestment grade assets we also examine the critical re-ratings across the investment grade threshold using Eq. (7). Rigobon (2002) highlighted that after Mexico's upgrade to investment grade in 2000, foreign investors piled into investing in Mexican assets. It is likely that the foreign investment channel will magnify the effects of sovereign rating events on stock market stability.

$$
\begin{array}{rl}
R M_{i, t}=\alpha+\beta_{1} & R M_{i, t-1}+\beta_{2} \text { Rating }_{i, t}+\beta_{3} \text { notch_w }_{i, t}+\beta_{4} \text { Crisis }_{t}+\beta_{5} \text { Crisis }_{t} \\
& \times \text { notch_w } \text { w }_{i, t}+\beta_{6} I G_{-} \text {chg } g_{i, t}+\beta_{7} \text { notch_w }_{i, t} \times I G_{-} \text {chg }_{i, t} \\
& +\beta_{8} \text { notch_w }_{i, t} \times I G_{-} \text {chg }_{i, t} \times \text { Crisis }_{t}+\beta_{9} X_{i, t}+u_{i, t}
\end{array}
$$

where the dependent variables represented by $R M_{i, t}$ and the independent variables Rating $_{i, t}$, notch_wi,t and Crisist are as defined previously and $I G_{-}$chg $g_{i, t}$ is an indicator variable that takes a value of 1 when there has been a rating change associated with a change in investment grade status and 0 otherwise. 
Lastly, we re-estimate Eq. (5) with individual crises to compare the impact of different episodes of financial crises on the higher moments of stock return distributions. We expect that debt-related crises will be more responsive to sovereign re-ratings than other types of financial crises and hence the impacts on higher moments should be greater.

\section{Results}

\subsection{Rating impact on realized higher moments of stock returns during crises}

Our primary concern with regard to our baseline empirical test rests with the outcome for the weekly intensity of re-rating variable (notch_w), especially during periods of financial crises (hence, the interaction term with Crisis). Notch_w is the weekly cumulative change in rating scores. It is advantageous over event indicator variables used to assess market reaction in prior research (see, for example, Ferreira and Gama (2007) and Gande and Parsley (2005)) as it is a continuous variable that can capture the intensity of rating activity within the week of a rating event.

$<$ Insert Table 4>

Table 4 reports the impact of notch_w on local stock market realized volatility, skewness and kurtosis. In normal times, notch_w is only significant in affecting RV upon a downgrade. The economic impact is not strong with a one-notch downgrade increasing RV by 4 basis points. A possible explanation is that during normal times the adjustment to ratings information in equity markets is instantaneous so our weekly measures are not significantly affected due to price reversals. 
However, financial crises appear to prolong and heighten the sensitivity of realized moments to sovereign re-ratings information. When all crises are considered together, the estimated coefficients on crisis*notch_w are positive and significant indicating that financial crises strengthens the impact of both upgrades and downgrades but affect different higher moments. Across ALL crises, a one-notch upgrade during a crisis is associated with a significant increase in the right-skew by 1.39 percent. A downgrade has a statistically and economically more significant effect on the second and fourth realized moment. A one-notch downgrade during a financial crisis can increase RV by an additional 8 basis points (total impact from a one-notch downgrade on RV during a financial crisis is thus 12 basis points) and increase RK by 7.25\%. Taken together, there is evidence to indicate that sovereign re-ratings do have asymmetric impacts on higher moment stock market returns with the downgrades having a stronger effect than upgrades. We also find that sovereign credit re-ratings during times of financial crises do present destabilizing effects on stock markets by increasing the realized volatility, skewness and kurtosis in market returns. This is consistent with the effects of funding constraints theorized by Brunnermeier and Pedersen (2009) to have implications for higher moments of returns. The evidence indicates that deteriorating sovereign governance results in sovereign rating downgrades that work to increase the cost of capital for firms within that country thereby increasing variability of stock price movements and ultimately, financial instability.

In terms of the control variables, a few brief observations can be made. There is significant positive serial correlation in RV and RK indicating that it is necessary to account for this behavior in higher moments. As expected, there is a positive relationship between a country’s economic performance proxied by Log_GDP and the 
degree of positive skewness in equity market returns. Currency volatility is also significant in the manner expected as an increase in FX volatility ( $F X \_v o l$ ) is associated with an increase in realized volatility and left-skew in equity returns. A tight (loose) monetary policy stance works to reduce (increase) the realized volatility in equity market returns but the economic impact is minimal. There is no significant relationship between the underlying rating level of a country and the realized higher moments and this is likely due to the degree of sovereign creditworthiness being already captured by the set of macroeconomic control variables that are known to determine sovereign credit ratings (Hill and Faff, 2010).

\subsection{Rating impact from single vs. multi-notch rating changes}

Table 5 reports the effects of small (one-notch) and large (multi-notch) sovereign credit re-ratings on higher return moments across all past financial crises. The results are striking as there is a clear asymmetry in the effect of rating downgrades over upgrades. Single-notch upgrades significantly increase RS during normal times but large multi-notch upgrades exert an even stronger economic impact and equity returns become more right skewed in response to multi-notch upgrades during financial crises. On the other hand, both small and large downgrades have a very significant effect on RV and the impact of all downgrades is heightened during financial crises. This implies that procyclical rating revisions by credit rating agencies do exert destabilizing effects on stock markets during financial crises as downgrades given in times of financial distress and economic downturn will increase RV and disrupt equity markets. This finding corroborates Fei, Fuertes and Kalotychou's (2012) related finding on the need to account for differences in credit rating migration over the business cycle for capital management purposes. Lastly, we find that while 
large downgrades affect RK during normal times, the effects are not amplified during crises.

$<$ Insert Table 5 $>$

\subsection{Rating impact from the investment grade threshold}

Table 6 reports the effects of sovereign credit re-ratings on realized higher moments of returns during all historical financial crises. This table again confirms that sovereign re-ratings have an asymmetric impact on the second, third and fourth moment of equity market returns. Upgrades to investment grade status are surprisingly insignificant and do not have incremental impact over and above the positive effect of upgrades in general during financial crises. However, the loss of investment grade status due to a downgrade is economically significant in increasing left-skew during financial crises. Interestingly, downgrades in general increase RV and RK during financial crises but there are no incremental investment grade threshold effects during crises.

Taken together the evidence indicates that downgrades resulting in a loss of investment grade status is destabilizing for equity markets and increases the left-skew of equity market returns. This is consistent with crises being times of confusion and contagion and the dispersion of negative news like a loss of investment grade status for a country works to increase investor heterogeneity in equity markets as reflected in greater negative skewness. This result corroborates with Hong and Stein's (2003) theory concerning information dispersion within financial markets.

$<$ Insert Table 6> 


\subsection{Rating impact across different types of financial crises}

Tables 7 to 9 report the effects of sovereign credit re-ratings information on realized volatility, skewness and kurtosis respectively during the various major financial crises occurring over our sample period (Asian, Russian, Tech, European and Global financial crises). It is apparent from the results reported in Table 7, that $\mathrm{RV}$ is the most sensitive to sovereign rating changes during debt-related crises. During the two main debt crises (European and Russian Debt Crises), realized equity market volatility was extra sensitive to both sovereign rating upgrades and downgrades but the effect of downgrades was both statistically and economically stronger. A one-notch downgrade during the RDC increased RV by 0.0044 per cent compared with an increase of only 0.0005 per cent for a one notch upgrade during the EDC.

\section{$<$ Insert Table 7 >}

In Table 8, upgrades are shown to increase the right-skew in equity markets during all crises and the Asian financial crisis (AFC). This corroborates Kaminsky and Schmukler's (1999) earlier results showing that equity market returns were very sensitive to sovereign rating information during the AFC. We extend upon their earlier findings by documenting the significant effect on skewness in equity market returns as well. Sovereign rating downgrades appear to exert differential effects during debt versus non-debt related crises. In the 2001-2002 Tech Bust, downgrades increased left-skew in equity markets but during the Russian debt crisis, downgrades were actually received positively by equity market participants resulting in an increase in right-skew in equity market returns. It is possible that during a debt crisis, a rating downgrade can provide the certainty for financial market participants that the 
debt situation is not as bad as anticipated and this can become good news for investors. This result corroborates with Beber and Brandt's (2010) finding on macroeconomic news effects in bond markets during bad times.

$<$ Insert Table 8>

In Table 9, it is shown that realized kurtosis (RK) is only affected by sovereign rating downgrades. Again this confirms the strong asymmetric effect of sovereign re-ratings on higher moments of equity market returns. During all financial crises and the 2001-2002 Tech bust realized kurtosis was significantly heightened by sovereign downgrades and the economic impacts were significant. A one-notch downgrade during the tech bust increased realized kurtosis by 24 percent and across ALL crises the effect was a milder 7.25 percent increase.

$<$ Insert Table 9>

Consistent with our conjecture, we do find evidence that indicates on balance that sovereign re-ratings are particularly destabilizing during debt crises and credit fuelled crises like the tech boom-bust which saw much debt raising to fund investments in the Information Technology sector prior to 2001. This corroborates Brunnermeier and Pedersen's (2009) view on funding constraints within financial markets and how it can ultimately lead to greater volatility, excess kurtosis and negative skewness. The sensitivity of equity markets to debt crises is not surprising as assessments on sovereign creditworthiness are crucial when there is an underlying fiscal debt problem in the economy. There are significant long-term economic and 
reputational consequences for a sovereign obligor and companies within a country to default on their debts. Thus, sovereign re-ratings in times of crises and confusion also affect aggregate stock market return distributions and this finding has important implications for risk managers and policy makers.

\section{Conclusions}

In this paper we examine the effects of sovereign re-ratings on the second, third and fourth realized sample moments of national stock markets returns during all major financial crises in recent history. We address four related questions: 1) Do sovereign re-ratings have a greater impact on higher moments during times of financial crises? 2) Are there asymmetric impacts on higher moments with downgrades being more significant than upgrades? 3) Does the nature of the re-rating matter in terms of size and investment grade status? 4) Are sovereign re-ratings more impactful in debt crises?

First, we find that stock markets react significantly to ratings announcements during financial crises. In times of crises, sovereign re-ratings provide more incremental information for higher stock return moments than country-specific macroeconomic determinants. Second, we find that there are asymmetric effects during financial crises in that downgrades are consistently more significant than upgrades in increasing realized volatility and kurtosis. Both upgrades and downgrades affect skewness in times of crises in the expected direction. Third, during crises only multi-notch upgrades significantly increase RV. The loss of investment grade status significantly increases the left-skew of equity market returns during financial crises but the upgrade to investment grade is less important. Lastly, the impact of re-ratings is generally stronger in debt-related crises. 
Taken together our evidence shows that financial crises do indeed increase the awareness of stock market participants to sovereign re-ratings and this works to heighten financial market instability captured in the dynamics of higher moments during times of financial crises. Corroborating Cumming, Hou and Wu (2014), we also find that sovereign governance as captured by sovereign credit ratings is important for firm valuations, especially during financial crises. This suggests that rating agencies’ procyclical rating methods presents a source of uncertainty during periods of financial crises and clear communication regarding revisions is critical during financial crises.

Future research in this area should focus on understanding the responses of different types of investors (e.g., retail vs. institutional) to credit rating information during financial crises. Moreover, rating impacts on higher return moments should be carefully examined to fully capture the true impact of ratings activity on stock performance. 


\section{References}

Albuquerque, R. (2012), 'Skewness in Stock Returns: Reconciling the Evidence on Firm versus Aggregate Returns,' Review of Financial Studies, Vol.25, No.5, pp.1630-1673.

Almeida, H, I. Cunha, M. Ferreira and F. Restrepo (2014), 'The Real Effects of Credit Ratings: The Sovereign Ceiling Channel,' working paper, University of Illinois at Urbana-Champaign.

Alsakka, R. and O. Ap Gwilym (2012a), 'Rating Agencies' Signals During the European Sovereign Debt Crisis: Market Impact and Spillovers,' Journal of Economic Behaviour and Organisation, forthcoming.

Alsakka, R. and O. Ap Gwilym (2012b), 'Rating Agencies' Credit Signals: An Analysis of Sovereign Watch and Outlook,' International Review of Financial Analysis, Vol.21, pp. 45-55.

Alsakka, R. and O. Ap Gwilym (2010), 'Leads and Lags in Sovereign Credit Ratings,'Journal of Banking and Finance, Vol.34, No.11, pp. 2614-2626.

Andersen, T. G. and T. Bollerslev (1998), 'Answering the Skeptics: Yes, Standard Volatility Models Do Provide Accurate Forecasts,' International Economic Review, Vol.39, No.4, pp. 885-905.

Andersen, T., T. Bollerslev, F. Diebold and P. Labys (2003), 'Modelling and Forecasting Realized Volatility,' Econometrica, Vol. 71, No.2, pp. 579-625.

Barndorff-Niesen, O. E. and N. Shephard (2001), 'Non-Gaussian Ornstein Uhlenbeck - Based Models and Some of Their Uses in Financial Economics,' Journal of the Royal Statistical Society, Series B 63, pp. 167-241.

Beber, A. and M.W. Brandt (2010), 'When It Cannot Get Better or Worse: The Asymmetric Impact of Good and Bad News on Bond Returns in Expansions and Recessions,' Review of Finance, Vol. 14, pp. 119-155.

Bedendo, M. and P. Colla (2013), 'Sovereign and Corporate Credit Risk: Evidence from the Eurozone,' working paper, Bocconi University.

Brooks, R., R. Faff, D. Hillier, D. and J. Hillier (2004), 'The National Market Impact of Sovereign Rating Changes,' Journal of Banking and Finance, Vol. 28, pp. 233250.

Brunnermeier, M. and L. Pedersen (2009), 'Market Liquidity and Funding Liquidity,' The Review of Financial Studies, Vol. 22, pp. 2201-2238.

Bank for International Settlements (BIS) Committee on the Global Financial System, (2011), 'The Impact of Sovereign Credit Risk on Bank Funding Conditions.' Bank for International settlements CGFS Papers No. 43. (Available at: http://www.bis.org/publ/cgfs43.pdf)

Cumming, D., W. Hou and E. Wu (2014), 'The Value of Home-Country Governance for Cross-listed Stocks,' The European Journal of Finance, In-press.

Do, H., R. Brooks, S. Treepongkaruna and E. Wu (2014), 'The Effects of Sovereign Rating Drifts on Financial Return Distributions: Evidence from the European Union,' International Review of Financial Analysis, Vol. 34, pp. 5-20.

Fei, F., A.-M Fuertes and E. Kalotychou (2012), 'Credit Rating Migration Risk and Business Cycles,' Journal of Business, Finance and Accounting, Vol. 39, pp. 229-263.

Ferreira, M.A. and P.M. Gama (2007), 'Does Sovereign Debt Ratings News Spill Over to International Stock Markets?,' Journal of Banking and Finance, Vol. 31, pp. 3162-3182.

Gande, A. and D.C. Parsley (2005), 'News Spillovers in the Sovereign Debt Market,' Journal of Financial Economics, Vol. 75, pp. 691-734. 
Harvey, C. and A. Siddique (2000), 'Conditional Skewness in Asset Pricing Tests,' Journal of Finance, Vol. 55, pp. 1263-1295.

Hill, P., E. Bissoondoyal-Bheenick and R. Faff (2014), 'Sovereign Credit Risk Spillover to Domestic Firms,' Working paper, University of Bristol.

Hill, P., R. Brooks and R. Faff (2010), 'Variations in Sovereign Credit Quality Assessments Across Rating Agencies,' Journal of Banking and Finance, Vol. 34, pp. $1327-1343$.

Hill, P. and R. Faff (2010), 'The Market Impact of Relative Agency Activity in the Sovereign Ratings Market,' Journal of Business Finance and Accounting, Vol. 37, pp. 1309-1347.

Hong, H. and J. Stein (2003), 'Differences of Opinion, Short Sales Constraints and Market Crashes,' Review of Financial Studies, Vol. 6, pp. 473-506.

International Monetary Fund (IMF) (2010), 'Resolving the Crisis Legacy and Meeting New Challenges to Financial Stability,' IMF Global Financial Stability Report: Meeting new Challenges to Stability and Building a Safer System (April).

Kaminsky, G., G. Reinhart and C. Vegh (2003), 'The Unholy Trinity of Financial Contagion,' Journal of Economic Perspectives, Vol. 17, pp. 51-74.

Kaminsky, G. and S.L. Schmukler (2002), 'Emerging Market Instability: Do Sovereign Ratings Affect Country Risk and Stock Returns?,' World Bank Economic Review, Vol. 16, No.2, pp. 171-195.

Kaminsky G. and S. L. Schmukler (1999), 'What Triggers Market Jitters? A Chronicle of the Asian crisis,' Journal of International Money and Finance, Vol. 18, pp. 537-560.

Michaelides, A., A. Milidonis, G. Nishiotis and P. Papakyriakou (2014), 'The Adverse Effects of Systematic Leakage Ahead of Official Sovereign Debt Rating Announcements,' Journal of Financial Economics, forthcoming.

Reisen, H. and J. Von Maltzan (1999), 'Boom and Bust and Sovereign Ratings,' International Finance, Vol. 2, pp. 273-293.

Rigobon, R. (2002), 'The Curse of Non-investment Grade Countries,' Journal of Development Economics, Vol. 69, pp. 423-449. 
Figure 1. Distribution of sovereign credit rating revisions over time: 1996-2013
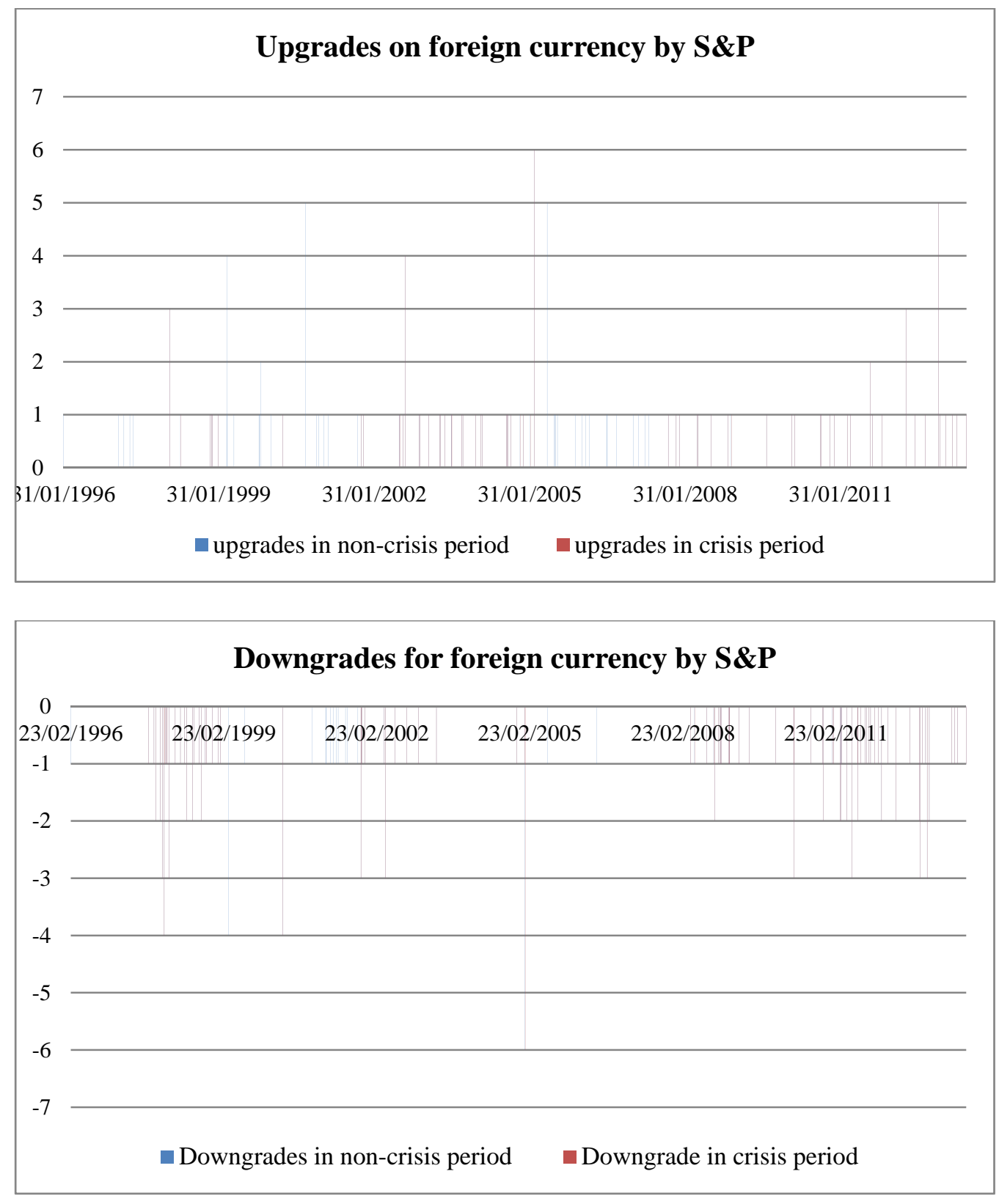

Notes: This figure shows the weekly cumulative sovereign credit rating upgrades and downgrades (notch_w) issued by Standard and Poors (S\&P) during non-crisis and major financial crisis periods. 
Table 1. Summary of sovereign credit rating events

\begin{tabular}{|c|c|c|c|c|c|c|}
\hline & \multicolumn{2}{|c|}{ Upgrades } & \multicolumn{2}{|c|}{ Downgrades } & \multicolumn{2}{|c|}{ All } \\
\hline & Frequency & Percent & Frequency & Percent & Frequency & Percent \\
\hline \multicolumn{7}{|c|}{ Panel A: Number of events by size of re-rating } \\
\hline 1 & 96 & $91 \%$ & 84 & $72 \%$ & 180 & $81 \%$ \\
\hline 2 & 2 & $2 \%$ & 20 & $17 \%$ & 22 & $10 \%$ \\
\hline 3 & 2 & $2 \%$ & 8 & $7 \%$ & 10 & $5 \%$ \\
\hline 4 & 2 & $2 \%$ & 3 & $3 \%$ & 5 & $2 \%$ \\
\hline$>=5$ & 4 & $4 \%$ & 1 & $1 \%$ & 5 & $2 \%$ \\
\hline Total & 106 & & 116 & & 222 & \\
\hline \multicolumn{7}{|c|}{ Panel B: Number of events by scale of rating change } \\
\hline $\begin{array}{l}\text { Single } \\
\text { notch }\end{array}$ & 96 & $91 \%$ & 84 & $72 \%$ & 180 & $81 \%$ \\
\hline $\begin{array}{l}\text { Multi- } \\
\text { notch }\end{array}$ & 10 & $9 \%$ & 32 & $28 \%$ & 42 & $19 \%$ \\
\hline \multicolumn{7}{|c|}{ Panel C: Number of events in crisis vs no-crisis periods } \\
\hline Crisis & 68 & $64 \%$ & 101 & $87 \%$ & 169 & $76 \%$ \\
\hline No-crisis & 38 & $36 \%$ & 15 & $13 \%$ & 53 & $24 \%$ \\
\hline \multicolumn{7}{|c|}{ Panel D: Number of events by development status } \\
\hline Emerging & 86 & $81 \%$ & 73 & $63 \%$ & 159 & $72 \%$ \\
\hline Developed & 20 & $19 \%$ & 43 & $37 \%$ & 63 & $28 \%$ \\
\hline
\end{tabular}

Notes: This table reports the number of upgrades and downgrades given by S\&P in our sample. Panel A shows the frequency of sovereign rating changes by number of notches, while Panel B shows the breakdown of the sovereign rating events into single and multi-notch changes. Panel $\mathrm{C}$ shows the number of rating events occurring during financial crisis and noncrisis periods. Panel D reports the number of rating events for emerging and developed countries in our sample. 
Table 2. Distribution of sovereign credit rating changes by country

\begin{tabular}{|c|c|c|c|c|c|c|c|c|c|}
\hline Country & Upgrades & $\begin{array}{l}\text { Single } \\
\text { notch }\end{array}$ & $\begin{array}{c}\text { Multi- } \\
\text { notch }\end{array}$ & $\begin{array}{c}\text { Up_ } \\
\text { IG }\end{array}$ & Downgrades & $\begin{array}{l}\text { Single } \\
\text { notch }\end{array}$ & $\begin{array}{l}\text { Multi- } \\
\text { notch }\end{array}$ & $\begin{array}{c}\text { Down_- } \\
\text { IG }\end{array}$ & Total \\
\hline Argentina & 5 & 4 & 1 & 0 & 11 & 10 & 1 & 0 & 16 \\
\hline Australia & 2 & 2 & 0 & 0 & 0 & 0 & 0 & 0 & 2 \\
\hline Austria & 0 & 0 & 0 & 0 & 1 & 1 & 0 & 0 & 1 \\
\hline Belgium & 0 & 0 & 0 & 0 & 1 & 1 & 0 & 0 & 1 \\
\hline Brazil & 7 & 7 & 0 & 1 & 2 & 2 & 0 & 0 & 9 \\
\hline Canada & 1 & 1 & 0 & 0 & 0 & 0 & 0 & 0 & 1 \\
\hline Chile & 3 & 3 & 0 & 0 & 0 & 0 & 0 & 0 & 3 \\
\hline China & 6 & 6 & 0 & 0 & 1 & 1 & 0 & 0 & 7 \\
\hline Colombia & 3 & 3 & 0 & 1 & 0 & 0 & 0 & 0 & 3 \\
\hline Cyprus & 2 & 2 & 0 & 0 & 8 & 5 & 3 & 1 & 10 \\
\hline Czech & 2 & 1 & 1 & 0 & 0 & 0 & 0 & 0 & 2 \\
\hline \multicolumn{10}{|l|}{ Republic } \\
\hline Greece & 6 & 3 & 3 & 0 & 10 & 4 & 6 & 1 & 16 \\
\hline Hong & 6 & 6 & 0 & 0 & 1 & 1 & 0 & 0 & 7 \\
\hline \multicolumn{10}{|l|}{ Kong } \\
\hline Hungary & 3 & 3 & 0 & 0 & 5 & 5 & 0 & 1 & 8 \\
\hline Iceland & 0 & 0 & 0 & 0 & 4 & 3 & 1 & 1 & 4 \\
\hline India & 2 & 2 & 0 & 0 & 1 & 1 & 0 & 0 & 3 \\
\hline Indonesia & 8 & 5 & 3 & 0 & 11 & 7 & 4 & 0 & 19 \\
\hline Ireland & 2 & 2 & 0 & 0 & 6 & 5 & 1 & 0 & 8 \\
\hline Israel & 2 & 2 & 0 & 0 & 0 & 0 & 0 & 0 & 2 \\
\hline Italy & 0 & 0 & 0 & 0 & 3 & 2 & 1 & 0 & 3 \\
\hline Japan & 1 & 1 & 0 & 0 & 4 & 4 & 0 & 0 & 5 \\
\hline Korea & 7 & 6 & 1 & 1 & 4 & 1 & 3 & 1 & 11 \\
\hline Malaysia & 3 & 3 & 0 & 1 & 4 & 3 & 1 & 1 & 7 \\
\hline Malta & 0 & 0 & 0 & 0 & 2 & 2 & 0 & 0 & 2 \\
\hline New & 1 & 1 & 0 & 0 & 1 & 1 & 0 & 0 & 2 \\
\hline \multicolumn{10}{|l|}{ Zealand } \\
\hline Pakistan & 4 & 4 & 0 & 0 & 8 & 5 & 3 & 0 & 12 \\
\hline Philippines & 4 & 4 & 0 & 0 & 2 & 2 & 0 & 0 & 6 \\
\hline Portugal & 1 & 1 & 0 & 0 & 6 & 3 & 3 & 1 & 7 \\
\hline Slovak & 6 & 6 & 0 & 1 & 1 & 1 & 0 & 0 & 7 \\
\hline \multicolumn{10}{|l|}{ Republic } \\
\hline South & 2 & 2 & 0 & 0 & 1 & 1 & 0 & 0 & 3 \\
\hline \multicolumn{10}{|l|}{ Africa } \\
\hline Spain & 2 & 2 & 0 & 0 & 6 & 3 & 3 & 1 & 8 \\
\hline Taiwan & 0 & 0 & 0 & 0 & 2 & 2 & 0 & 0 & 2 \\
\hline Thailand & 2 & 2 & 0 & 1 & 3 & 2 & 1 & 1 & 5 \\
\hline Turkey & 6 & 6 & 0 & 0 & 2 & 2 & 0 & 0 & 8 \\
\hline Uruguay & 1 & 1 & 0 & 0 & 0 & 0 & 0 & 0 & 1 \\
\hline Venezuela & 6 & 5 & 1 & 0 & 5 & 4 & 1 & 0 & 11 \\
\hline $\begin{array}{l}\text { Total } \\
\text { number of } \\
\text { rating } \\
\text { changes }\end{array}$ & 106 & 96 & 10 & 6 & 116 & 84 & 32 & 9 & 222 \\
\hline
\end{tabular}

Notes: This table reports the number of upgrades and downgrades instigated by S\&P for each country as well as the breakdown by size of the rating change (single notch vs. multiple notches). It also shows the number of upgrades from non-investment to investment grade status (Up_IG) and the number of downgrades from investment to non-investment grade (Down_IG). Total gives the number of upgrades and downgrades combined. 
Table 3. Average realized higher moments by country

\begin{tabular}{|c|c|c|c|c|}
\hline Country & $\mathrm{RR}$ & $\mathrm{RV}$ & RS & RK \\
\hline Argentina & 0.0025 & 0.0489 & -0.3461 & 4.2521 \\
\hline Australia & 0.0009 & 0.0205 & -1.1495 & 7.4695 \\
\hline Austria & 0.0011 & 0.0326 & -1.7611 & 16.0922 \\
\hline Belgium & 0.0014 & 0.1093 & -0.1418 & 413.2171 \\
\hline Brazil & 0.0002 & 0.0867 & -19.2280 & 500.4774 \\
\hline Canada & 0.0009 & 0.0242 & -1.1319 & 9.1878 \\
\hline Chile & 0.0013 & 0.0208 & -0.8000 & 7.7715 \\
\hline China & 0.0015 & 0.0364 & -0.0941 & 3.2357 \\
\hline Colombia & 0.0040 & 0.1201 & 0.2760 & 273.6832 \\
\hline Cyprus & -0.0048 & 0.0642 & -0.2174 & 2.3600 \\
\hline Czech Republic & -0.0011 & 0.0364 & -1.4617 & 13.6936 \\
\hline Greece & 0.0002 & 0.0429 & -0.0839 & 3.0767 \\
\hline Hong Kong & 0.0009 & 0.0351 & -0.4529 & 3.2708 \\
\hline Hungary & 0.0013 & 0.0406 & -1.1263 & 8.7257 \\
\hline Iceland & -0.0060 & 0.0686 & -12.1969 & 184.9213 \\
\hline India & 0.0020 & 0.0351 & -0.2791 & 2.0301 \\
\hline Indonesia & 0.0023 & 0.0397 & -0.4285 & 4.6344 \\
\hline Ireland & 0.0007 & 0.0313 & -1.7476 & 14.3488 \\
\hline Israel & 0.0017 & 0.0284 & -0.6033 & 2.7940 \\
\hline Italy & -0.0001 & 0.0343 & -0.5672 & 1.1280 \\
\hline Japan & 0.0006 & 0.0334 & -0.0603 & 3.8592 \\
\hline Korea & 0.0009 & 0.0416 & -0.4114 & 2.8970 \\
\hline Malaysia & 0.0006 & 0.0297 & 0.1151 & 10.8207 \\
\hline Malta & 0.0077 & 0.1683 & 22.4151 & 526.3532 \\
\hline New Zealand & 0.0003 & 0.0174 & -0.4835 & 3.6655 \\
\hline Pakistan & 0.0030 & 0.0378 & -0.8357 & 3.5022 \\
\hline Philippines & 0.0015 & 0.0296 & -0.9076 & 5.6402 \\
\hline Portugal & 0.0012 & 0.0258 & -1.0568 & 7.6092 \\
\hline Slovak Republic & 0.0010 & 0.0269 & -0.5114 & 15.7256 \\
\hline South Africa & 0.0024 & 0.0269 & -0.0766 & 3.7856 \\
\hline Spain & 0.0012 & 0.0312 & -0.8245 & 5.0454 \\
\hline Taiwan & 0.0005 & 0.0338 & -0.2644 & 2.6789 \\
\hline Thailand & 0.0001 & 0.0384 & -0.2647 & 4.7240 \\
\hline Turkey & 0.0049 & 0.0573 & -0.0958 & 3.5036 \\
\hline Uruguay & -0.1929 & 0.7999 & -4.2587 & 18.7826 \\
\hline Venezuela & 0.0077 & 0.0443 & 0.8786 & 7.0249 \\
\hline
\end{tabular}

Notes: This table reports the average values of weekly realized returns (RR), realized volatility (RV), realized skewness (RS) and realized kurtosis (RK) for each sample country. Our full sample comprises 36 national stock market indices over the period 2 January 1996 to 13 November 2013. 
Table 4. Impact of sovereign re-ratings on realized higher moments

\begin{tabular}{|c|c|c|c|c|c|c|}
\hline \multirow[b]{2}{*}{ Dependent var. } & \multicolumn{3}{|c|}{ Upgrades } & \multicolumn{3}{|c|}{ Downgrades } \\
\hline & RV & RS & RK & RV & RS & RK \\
\hline \multirow[t]{2}{*}{ RMt-1 } & 0.1431 & 0.0215 & 0.1338 & $0.3661^{* * *}$ & -0.0045 & $0.2278^{* * *}$ \\
\hline & $(0.2584)$ & $(0.7627)$ & $(0.2701)$ & $(0.0030)$ & (0.9623) & $(0.0068)$ \\
\hline \multirow[t]{2}{*}{ rating } & 0.0001 & -0.1031 & 1.3278 & 0.0000 & 0.0661 & 0.1676 \\
\hline & $(0.3260)$ & $(0.1446)$ & $(0.4357)$ & $(0.4522)$ & $(0.2391)$ & $(0.8624)$ \\
\hline \multirow[t]{2}{*}{ notch_w } & -0.0000 & 0.2914 & -1.4991 & $0.0004^{*}$ & 0.0014 & -2.6882 \\
\hline & $(0.6572)$ & $(0.1829)$ & $(0.4637)$ & $(0.0948)$ & (0.9932) & $(0.1509)$ \\
\hline \multirow[t]{2}{*}{ Crisis } & 0.0009 & -1.0167 & 4.6891 & 0.0001 & $-0.7944^{*}$ & 0.9555 \\
\hline & $(0.1476)$ & $(0.1638)$ & $(0.4742)$ & $(0.8865)$ & $(0.0745)$ & $(0.8954)$ \\
\hline \multirow[t]{2}{*}{ Crisis*notch_w } & -0.0005 & $1.3885^{* *}$ & -0.6238 & $0.0008^{*}$ & -0.1655 & $7.2514 *$ \\
\hline & $(0.3469)$ & $(0.0160)$ & $(0.9435)$ & $(0.0719)$ & (0.6397) & $(0.0670)$ \\
\hline \multirow[t]{2}{*}{ Log_GDP } & -0.0017 & $2.6904 * * *$ & -1.7116 & -0.0012 & 1.2442 & 6.0507 \\
\hline & $(0.2143)$ & $(0.0011)$ & $(0.8991)$ & $(0.1386)$ & (0.1024) & $(0.6226)$ \\
\hline \multirow[t]{2}{*}{ FX_vol } & $0.0878 * * *$ & $=-226.606^{* * *}$ & -245.453 & 0.0052 & 12.2449 & -273.619 \\
\hline & $(0.0048)$ & $(0.0000)$ & $(0.8079)$ & $(0.6574)$ & $(0.6121)$ & $(0.3854)$ \\
\hline \multirow[t]{2}{*}{ Mon_policy } & -0.0002 & 0.3515 & -0.9603 & $-0.0008^{* *}$ & -0.2248 & 3.9630 \\
\hline & $(0.4165)$ & $(0.3382)$ & $(0.8261)$ & $(0.0320)$ & $(0.4896)$ & $(0.5177)$ \\
\hline \multirow[t]{2}{*}{ Intercept } & 0.0144 & $-21.4225^{* * *}$ & 22.4212 & 0.0117 & $-12.0893 *$ & -38.3638 \\
\hline & $(0.2140)$ & $(0.0025)$ & $(0.8515)$ & (0.1173) & $(0.0833)$ & $(0.7457)$ \\
\hline Country F.E & YES & YES & YES & YES & YES & YES \\
\hline adj. R-sq & 0.0610 & 0.0949 & 0.0157 & 0.2984 & 0.0132 & 0.0706 \\
\hline $\mathrm{N}$ & 212 & 211 & 211 & 232 & 232 & 232 \\
\hline
\end{tabular}

Notes: This table presents the baseline model panel estimation results for stock market realized volatility (RV), skewness (RS), and kurtosis (RK), over the sample period from 2 January 1996 to 13 November 2013 for all 36 countries studied. Model specifications are based on Eq. (5) as follows $R M_{i, t}=\alpha+\beta_{1} R M_{i, t-1}+\beta_{2}$ Rating $_{i, t}+\beta_{3}$ notch $_{w_{i, t}}+\beta_{4}$ Crisis $_{t}+$ $\beta_{5}$ Crisis $_{t} \times$ notch $_{w_{i, t}}+\beta_{6} X_{i, t}+u_{i, t} . R M_{t-1}$ is the realized moment (i.e. RV, RS or RK) from the past week, Rating is the linear rating score and notch_w is the cumulative number of notches re-rated during the week. Crisis is an aggregate financial crisis indicator that takes on a value of one during crisis periods and zero otherwise and the crisis periods included are from Jul. 1997 - Jan. 1998: the Asian Financial Crisis (AFC); Aug. 1998 - Oct. 1998: the Russian Debt Crisis (RDC); Mar. 2000 - Sept. 2002 for the Tech/Terrorist (Tech) crisis of confidence; Jul. 2007 - May 2010: the Global Financial Crisis (GFC); and Dec. 2008 - Nov. 2013: the European Debt crisis (EDC). Crisis is a composite measure of all these major crises as well as the brief Brazilian (in Feb. 1999) and Turkish (Feb. 2001) crises. Log_GDP is the log of Gross Domestic Product, $F X_{-} v o l$ is the volatility of the local currency against the US dollar measured as weekly rolling standard deviations of the currency's returns, Mon_policy is a monetary regime indicator variable that takes a value of 1 when short-term interest rates increase and only revert to zero when interest rates are subsequently cut. Country fixed effects and clustered standard errors are used. *, ** and *** denote significance at the 10, 5 and 1\% levels (p-values are shown in parentheses). 
Table 5. Impact of single and multiple notch sovereign re-ratings on realized higher moments

\begin{tabular}{|c|c|c|c|c|c|c|}
\hline \multirow[b]{2}{*}{ Dependent Var. } & \multicolumn{3}{|c|}{ Upgrades } & \multicolumn{3}{|c|}{ Downgrades } \\
\hline & RV & RS & RK & RV & RS & RK \\
\hline \multirow[t]{2}{*}{ RMt-1 } & 0.1437 & 0.0164 & 0.1392 & $0.3837^{* * *}$ & -0.0035 & $0.2221 * *$ \\
\hline & $(0.2520)$ & $(0.8155)$ & $(0.2522)$ & $(0.0021)$ & $(0.9698)$ & $(0.0137)$ \\
\hline \multirow[t]{2}{*}{ rating } & 0.0001 & $-0.1277^{*}$ & 1.2561 & 0.0000 & 0.0815 & -0.1423 \\
\hline & $(0.3629)$ & $(0.0729)$ & $(0.4748)$ & $(0.2481)$ & $(0.2567)$ & $(0.8914)$ \\
\hline \multirow[t]{2}{*}{ crisis } & 0.0010 & -0.1680 & -2.3417 & -0.0007 & -1.4472 & 12.0454 \\
\hline & $(0.1757)$ & $(0.9062)$ & $(0.7981)$ & $(0.1444)$ & $(0.2585)$ & $(0.5053)$ \\
\hline \multirow[t]{2}{*}{ single_notch_w } & 0.0001 & $0.8883^{* *}$ & -2.6753 & $0.0006^{*}$ & -0.4469 & -1.8235 \\
\hline & $(0.7783)$ & $(0.0489)$ & $(0.5442)$ & $(0.0644)$ & $(0.3905)$ & $(0.7008)$ \\
\hline \multirow[t]{2}{*}{ multi_notch_w } & -0.0001 & 1.0896 & -7.1738 & $0.0015 * *$ & 0.1305 & $10.6923 *$ \\
\hline & (0.7799) & $(0.2071)$ & $(0.4428)$ & $(0.0300)$ & $(0.8173)$ & $(0.0833)$ \\
\hline \multirow[t]{2}{*}{ single_notch_w*crisis } & -0.0007 & 0.0410 & 9.4548 & $0.0017^{* *}$ & 0.9257 & -6.8048 \\
\hline & $(0.4734)$ & $(0.9801)$ & $(0.5132)$ & (0.0199) & $(0.5113)$ & $(0.7116)$ \\
\hline \multirow[t]{2}{*}{ multi_notch_w*crisis } & -0.0013 & $5.8075 * * *$ & -26.9535 & $0.0019 *$ & 0.1638 & 5.1109 \\
\hline & $(0.3245)$ & $(0.0006)$ & $(0.3486)$ & $(0.0964)$ & $(0.8681)$ & $(0.6926)$ \\
\hline Controls & YES & $Y E S$ & YES & YES & $Y E S$ & YES \\
\hline Country F.E. & YES & YES & YES & YES & YES & YES \\
\hline adj. R-sq & 0.0518 & 0.1076 & 0.0133 & 0.3036 & 0.0106 & 0.0615 \\
\hline $\mathrm{N}$ & 212 & 211 & 211 & 232 & 232 & 232 \\
\hline
\end{tabular}

Notes: This table presents the panel estimation results for stock market realized volatility (RV), skewness (RS), and kurtosis (RK), over the sample period from 2 January 1996 to 13 November 2013 for all 36 countries studied with the following model specifications (i.e. Eq. (6)): $R M_{i, t}=\alpha+\beta_{1} R M_{i, t-1}+\beta_{2}$ Rating $_{i, t}+\beta_{3}$ single_notch_w $w_{i, t}+\beta_{4}$ multi_notch_w $w_{i, t}+$ $\beta_{5}$ Crisis $_{t}+\beta_{6}$ Crisis $_{t} \times$ single_notch_w $w_{i, t}+\beta_{7}$ Crisis ${ }_{t} \times$ multi_notch_w $w_{i, t}+\beta_{8} X_{i, t}+u_{i, t}$. $R M_{t-1}$ is the realized moment (i.e. RV, RS or RK) from the past week, Rating is the average linear rating score for the week. Single_notch_w is an indicator variable that takes a value of 1 when notch_w is equal to 1 and zero otherwise. Multi_notch_w is an indicator variable that takes a value of 1 when notch_w is greater than 1 and zero otherwise. Crisis is an aggregate financial crisis indicator that takes on a value of one during any crisis period and zero otherwise and the crisis periods included are from Jul. 1997 - Jan. 1998: the Asian Financial Crisis (AFC); Aug. 1998 - Oct. 1998: the Russian Debt Crisis (RDC); Mar. 2000 - Sept. 2002: the Tech/Terrorist (Tech) crisis of confidence; Jul. 2007 - May 2010: the Global Financial Crisis (GFC); and Dec. 2008 - Nov. 2013: the European Debt crisis (EDC). Crisis is a composite measure of all these major crises as well as the brief Brazilian (in Feb. 1999) and Turkish (Feb. 2001) crises. Country fixed effects and clustered standard errors are used. $*, * *$ and $* * *$ denote significance at the 10,5 and $1 \%$ levels (p-values are shown in parentheses). 
Table 6. Impact of sovereign re-ratings across the investment grade demarcation on realized higher moments

\begin{tabular}{|c|c|c|c|c|c|c|}
\hline \multirow[b]{2}{*}{ Dependent Var. } & \multicolumn{3}{|c|}{ Upgrades } & \multicolumn{3}{|c|}{ Downgrades } \\
\hline & $\mathrm{RV}$ & RS & RK & $\mathrm{RV}$ & $\mathrm{RS}$ & RK \\
\hline RMt-1 & $\begin{array}{l}0.1430 \\
(0.2583)\end{array}$ & $\begin{array}{l}0.0211 \\
(0.7651)\end{array}$ & $\begin{array}{l}0.1348 \\
(0.2677)\end{array}$ & $\begin{array}{l}0.3712^{* * *} \\
(0.0037)\end{array}$ & $\begin{array}{l}-0.0216 \\
(0.8234)\end{array}$ & $\begin{array}{l}0.2301^{* * *} \\
(0.0066)\end{array}$ \\
\hline rating & $\begin{array}{l}0.0001 \\
(0.3380)\end{array}$ & $\begin{array}{l}-0.1038 \\
(0.1443)\end{array}$ & $\begin{array}{l}1.3671 \\
(0.4189)\end{array}$ & $\begin{array}{l}0.0000 \\
(0.5388)\end{array}$ & $\begin{array}{l}0.0756 \\
(0.1846)\end{array}$ & $\begin{array}{l}0.1879 \\
(0.8498)\end{array}$ \\
\hline notch_w & $\begin{array}{l}-0.0000 \\
(0.6071)\end{array}$ & $\begin{array}{l}0.2889 \\
(0.1855)\end{array}$ & $\begin{array}{l}-1.3481 \\
(0.5079)\end{array}$ & $\begin{array}{l}0.0003 \\
(0.1222)\end{array}$ & $\begin{array}{l}0.0175 \\
(0.9138)\end{array}$ & $\begin{array}{l}-2.7016 \\
(0.1435)\end{array}$ \\
\hline crisis & $\begin{array}{l}0.0010 \\
(0.1190)\end{array}$ & $\begin{array}{l}-1.0024 \\
(0.1820)\end{array}$ & $\begin{array}{l}3.7550 \\
(0.5551)\end{array}$ & $\begin{array}{l}0.0002 \\
(0.7855)\end{array}$ & $\begin{array}{l}-0.8873^{*} \\
(0.0921)\end{array}$ & $\begin{array}{l}-0.4125 \\
(0.9572)\end{array}$ \\
\hline crisis*notch_w & $\begin{array}{l}-0.0006 \\
(0.3127)\end{array}$ & $\begin{array}{l}1.3804^{* *} \\
(0.0178)\end{array}$ & $\begin{array}{l}-0.1027 \\
(0.9907)\end{array}$ & $\begin{array}{l}0.0008^{*} \\
(0.0935)\end{array}$ & $\begin{array}{l}-0.3233 \\
(0.4765)\end{array}$ & $\begin{array}{l}9.8735^{* *} \\
(0.0135)\end{array}$ \\
\hline IG_chg & $\begin{array}{l}0.0008 \\
(0.3868)\end{array}$ & $\begin{array}{l}0.2591 \\
(0.7216)\end{array}$ & $\begin{array}{l}-15.3535^{* *} \\
(0.0318)\end{array}$ & $\begin{array}{l}-0.0019 \\
(0.2534)\end{array}$ & $\begin{array}{l}3.3563 \\
(0.1890)\end{array}$ & $\begin{array}{l}12.0940 \\
(0.3835)\end{array}$ \\
\hline notch_w*IG_chg & $\begin{array}{l}0.0000 \\
(0.9999)\end{array}$ & $\begin{array}{l}0.0000 \\
(0.9999)\end{array}$ & $\begin{array}{l}0.0000 \\
(0.9999)\end{array}$ & $\begin{array}{l}0.0014 \\
(0.2376)\end{array}$ & $\begin{array}{l}-1.7649 \\
(0.1617)\end{array}$ & $\begin{array}{l}-7.8062 \\
(0.3005)\end{array}$ \\
\hline notch_w $*$ crisis $* I G \_c h g$ & $\begin{array}{l}0.0000 \\
(0.9999)\end{array}$ & $\begin{array}{l}0.0000 \\
(0.9999)\end{array}$ & $\begin{array}{l}0.0000 \\
(0.9999)\end{array}$ & $\begin{array}{l}-0.0006 \\
(0.4718)\end{array}$ & $\begin{array}{l}-0.8721^{*} \\
(0.0709)\end{array}$ & $\begin{array}{l}-3.6953 \\
(0.4341)\end{array}$ \\
\hline Controls & YES & YES & YES & YES & YES & YES \\
\hline Country F.E. & YES & YES & YES & YES & YES & YES \\
\hline adj. R-sq & 0.0592 & 0.0906 & 0.0165 & 0.2932 & 0.0207 & 0.0633 \\
\hline $\mathrm{N}$ & 212 & 211 & 211 & 232 & 232 & 232 \\
\hline
\end{tabular}

Notes: This table presents the panel estimation results for stock market realized volatility (RV), skewness (RS), and kurtosis (RK), over the sample period from 2 January 1996 to 13 November 2013 for all 36 countries studied with the following model specifications (i.e. Eq. (7)): $R M_{i, t}=\alpha+\beta_{1} R M_{i, t-1}+\beta_{2}$ Rating $_{i, t}+\beta_{3}$ notch_ $_{i, t}+\beta_{4}$ Crisis $_{t}+\beta_{5}$ Crisis $_{t} \times$ notch_w $w_{i, t}+\beta_{6} I G_{-}$chg $+\beta_{7} n o t c h \_w_{i, t} \times I G_{-}$chg $+\beta_{8}$ notch_w $w_{i, t} \times I G_{-}$chg $\times$Crisis $_{t}+$ $\beta_{9} X_{i, t}+u_{i, t} . R M_{t-1}$ is the realized moment (i.e. RV, RS or RK) from the past week, Rating is the linear rating score and notch_w is the cumulative number of notches re-rated during the week. $I G_{-}$chg is an indicator variable that takes a value of 1 when an upgrade or downgrade crosses the investment grade demarcation. Crisis is an aggregate financial crisis indicator that takes on a value of one during any crisis period and zero otherwise and the crisis periods included are from Jul. 1997 - Jan. 1998: the Asian Financial Crisis (AFC); Aug. 1998 - Oct. 1998: the Russian Debt Crisis (RDC); Mar. 2000 - Sept. 2002: the Tech/Terrorist (Tech) crisis of confidence; Jul. 2007 - May 2010: the Global Financial Crisis (GFC); and Dec. 2008 - Nov. 2013: the European Debt crisis (EDC). Crisis is a composite measure of all these major crises as well as the brief Brazilian (in Feb. 1999) and Turkish (Feb. 2001) crises. Country fixed effects and clustered standard errors are used. *, ** and *** denote significance at the 10, 5 and 1\% levels (p-values are shown in parentheses). 
Table 7. Impact of sovereign re-ratings on realized volatility across major financial crises

\begin{tabular}{|c|c|c|c|c|c|c|c|c|c|c|c|c|}
\hline \multirow{3}{*}{$\begin{array}{l}\text { Dependent var. } \\
\text { Crisis }\end{array}$} & \multicolumn{12}{|c|}{ RV } \\
\hline & \multicolumn{6}{|c|}{ Upgrades } & \multicolumn{6}{|c|}{ Downgrades } \\
\hline & ALL & AFC & RDC & TECH & EDC & GFC & ALL & AFC & RDC & TECH & EDC & GFC \\
\hline \multirow[t]{2}{*}{ RMt-1 } & 0.1431 & 0.1701 & 0.1620 & 0.1105 & 0.1644 & 0.1414 & $0.3661^{* * *}$ & $0.3945^{* * *}$ & ${ }^{*} 0.4586^{* * *}$ & $0.4291^{* * *}$ & $0.4319^{* * *}$ & * $0.4267 * * *$ \\
\hline & $(0.2584)$ & (0.1813) & $(0.2117)$ & $(0.2653)$ & (0.1918) & $(0.2853)$ & $(0.0030)$ & $(0.0009)$ & $(0.0007)$ & $(0.0003)$ & $(0.0004)$ & $(0.0008)$ \\
\hline \multirow[t]{2}{*}{ rating } & 0.0001 & 0.0001 & 0.0001 & 0.0001 & 0.0001 & 0.0001 & 0.0000 & 0.0000 & 0.0001 & 0.0001 & $0.0001^{* *}$ & 0.0001 \\
\hline & $(0.3260)$ & $(0.2480)$ & (0.1511) & $(0.2391)$ & $(0.1722)$ & $(0.3335)$ & $(0.4522)$ & (0.3629) & $(0.2519)$ & $(0.2490)$ & $(0.0466)$ & (0.2823) \\
\hline \multirow[t]{2}{*}{ notch_w } & -0.0000 & -0.0001 & -0.0001 & -0.0001 & -0.0001 & -0.0000 & 0.0004 & $0.0005^{* *}$ & $0.0006^{* *}$ & $0.0005^{* *}$ & 0.0005 & $0.0005^{*}$ \\
\hline & $(0.6572)$ & (0.5513) & $(0.1482)$ & $(0.4098)$ & $(0.2377)$ & $(0.6286)$ & $(0.1048)$ & $(0.0245)$ & $(0.0343)$ & $(0.0472)$ & $(0.1062)$ & $(0.0818)$ \\
\hline \multirow[t]{2}{*}{ Crisis } & 0.0009 & -0.0018 & -0.0004 & $0.0062 * * *$ & -0.0005 & 0.0010 & 0.0001 & 0.0008 & $0.0059^{*}$ & 0.0000 & -0.0007 & -0.0006 \\
\hline & $(0.1476)$ & $(0.4822)$ & $(0.4426)$ & $(0.0000)$ & $(0.3331)$ & $(0.1916)$ & $(0.8865)$ & $(0.5036)$ & $(0.0776)$ & (0.9999) & (0.1353) & (0.4279) \\
\hline \multirow[t]{2}{*}{ Crisis*notch_w } & -0.0005 & 0.0003 & 0.0003 & 0.0000 & $0.0005^{*}$ & -0.0003 & $0.0008^{*}$ & 0.0009 & $0.0044^{* *}$ & 0.0002 & 0.0007 & 0.0006 \\
\hline & (0.3469) & (0.7784) & (0.2195) & (0.9999) & $(0.0583)$ & $(0.8220)$ & (0.0719) & (0.3057) & $(0.0466)$ & $(0.2755)$ & $(0.1125)$ & $(0.4226)$ \\
\hline Controls & YES & YES & YES & YES & YES & YES & YES & YES & YES & YES & YES & YES \\
\hline Country F.E. & YES & YES & YES & YES & YES & YES & YES & YES & YES & YES & YES & YES \\
\hline adj. R-sq & 0.0610 & 0.0572 & 0.0570 & 0.0985 & 0.0520 & 0.0636 & 0.2984 & 0.2987 & 0.2831 & 0.2785 & 0.2795 & 0.2780 \\
\hline $\mathrm{N}$ & 212 & 212 & 212 & 212 & 212 & 212 & 232 & 232 & 232 & 232 & 232 & 232 \\
\hline
\end{tabular}

Notes: This table presents the baseline model panel estimation results for stock market realized volatility (RV) over the sample period from 2 January 1996 to 13 November 2013 for all 36 countries studied. Model specifications are based on Eq. (5) as follows $R M_{i, t}=\alpha+$ $\beta_{1} R M_{i, t-1}+\beta_{2}$ Rating $_{i, t}+\beta_{3}$ notch $_{w_{i, t}}+\beta_{4}$ Crisis $_{t}+\beta_{5}$ Crisis $_{t} \times$ notch $_{w_{i, t}}+\beta_{6} X_{i, t}+u_{i, t} . \quad R M_{t-1}$ is the realized moment (RV) from the past week, Rating is the average linear rating score during the week and notch_w is the cumulative number of notches re-rated during the week. Crisis is either the aggregate financial crisis indicator that takes on a value of one during ALL crisis periods and zero otherwise or during major individual crises. Crisis periods included are from Jul. 1997 - Jan. 1998: the Asian Financial Crisis (AFC); Aug. 1998 - Oct. 1998: the Russian Debt Crisis (RDC); Mar. 2000 - Sept. 2002: the Tech/Terrorist (Tech) crisis of confidence; Jul. 2007 - May 2010: the Global Financial Crisis (GFC); and Dec. 2008 - Nov. 2013: the European Debt crisis (EDC). Country fixed effects and clustered standard errors are used. $* *^{* *}$ and $* * *$ denote significance at the 10,5 and $1 \%$ levels (p-values are shown in parentheses). 
Table 8. Impact of sovereign re-ratings on realized skewness across major financial crises

\begin{tabular}{|c|c|c|c|c|c|c|c|c|c|c|c|c|}
\hline \multirow[t]{2}{*}{ Dependent var. } & \multicolumn{12}{|c|}{ RS } \\
\hline & \multicolumn{6}{|c|}{ Upgrades } & \multicolumn{6}{|c|}{ Downgrades } \\
\hline Crisis & ALL & AFC & RDC & TECH & EDC & GFC & ALL & AFC & GFC & RDC & TECH & EDC \\
\hline RMt-1 & $\begin{array}{l}0.0215 \\
(0.7627)\end{array}$ & $\begin{array}{l}0.0234 \\
(0.7357)\end{array}$ & $\begin{array}{l}0.0290 \\
(0.6823)\end{array}$ & $\begin{array}{l}0.0355 \\
(0.5989)\end{array}$ & $\begin{array}{l}0.0282 \\
(0.6757)\end{array}$ & $\begin{array}{l}0.0282 \\
(0.6814)\end{array}$ & $\begin{array}{l}-0.0045 \\
(0.9623)\end{array}$ & $\begin{array}{l}-0.0314 \\
(0.7541)\end{array}$ & $\begin{array}{l}0.0003 \\
(0.9977)\end{array}$ & $\begin{array}{l}-0.0122 \\
(0.8983)\end{array}$ & $\begin{array}{l}-0.0250 \\
(0.8000)\end{array}$ & $\begin{array}{l}-0.0136 \\
(0.8887)\end{array}$ \\
\hline rating & $\begin{array}{l}-0.1031 \\
(0.1446)\end{array}$ & $\begin{array}{l}-0.0752 \\
(0.3469)\end{array}$ & $\begin{array}{l}-0.1085 \\
(0.1611)\end{array}$ & $\begin{array}{l}-0.1101 \\
(0.1460)\end{array}$ & $\begin{array}{l}-0.1307^{*} \\
(0.0897)\end{array}$ & $\begin{array}{l}-0.1210 \\
(0.1105)\end{array}$ & $\begin{array}{l}0.0661 \\
(0.2391)\end{array}$ & $\begin{array}{l}0.0398 \\
(0.4561)\end{array}$ & $\begin{array}{l}0.0534 \\
(0.3658)\end{array}$ & $\begin{array}{l}0.0413 \\
(0.4532)\end{array}$ & $\begin{array}{l}0.0219 \\
(0.6680)\end{array}$ & $\begin{array}{l}0.0612 \\
(0.2865)\end{array}$ \\
\hline notch_w & $\begin{array}{l}0.2914 \\
(0.1829)\end{array}$ & $\begin{array}{l}0.3443^{*} \\
(0.0944)\end{array}$ & $\begin{array}{l}0.3469 \\
(0.2390)\end{array}$ & $\begin{array}{l}0.3331 \\
(0.1603)\end{array}$ & $\begin{array}{l}0.3934 \\
(0.2022)\end{array}$ & $\begin{array}{l}0.2925 \\
(0.2370)\end{array}$ & $\begin{array}{l}0.0014 \\
(0.9932)\end{array}$ & $\begin{array}{l}-0.1648 \\
(0.3725)\end{array}$ & $\begin{array}{l}-0.1282 \\
(0.4646)\end{array}$ & $\begin{array}{l}-0.2405 \\
(0.1266)\end{array}$ & $\begin{array}{l}-0.0330 \\
(0.8345)\end{array}$ & $\begin{array}{c}-0.2922 * \\
(0.0677)\end{array}$ \\
\hline Crisis & $\begin{array}{l}-1.0167 \\
(0.1638)\end{array}$ & $\begin{array}{l}-5.4035^{* *} \\
(0.0366)\end{array}$ & $\begin{array}{l}-0.4111 \\
(0.6494)\end{array}$ & $\begin{array}{l}3.9123^{* * *} \\
(0.0000)\end{array}$ & $\begin{array}{l}0.3480 \\
(0.6546)\end{array}$ & $\begin{array}{l}-0.6527 \\
(0.5672)\end{array}$ & $\begin{array}{l}-0.7944 * \\
(0.0745)\end{array}$ & $\begin{array}{l}-1.9648 * * \\
(0.0152)\end{array}$ & $\begin{array}{l}-0.9639 \\
(0.3118)\end{array}$ & $\begin{array}{l}-0.6284 \\
(0.2798)\end{array}$ & $\begin{array}{l}0.0000 \\
(0.9999)\end{array}$ & $\begin{array}{l}0.1088 \\
(0.8863)\end{array}$ \\
\hline Crisis*Notch_w & $\begin{array}{l}1.3885^{* *} \\
(0.0160)\end{array}$ & $\begin{array}{l}4.0415^{* * *} \\
(0.0012)\end{array}$ & $\begin{array}{l}-0.0065 \\
(0.9861)\end{array}$ & $\begin{array}{l}0.0000 \\
(0.9999)\end{array}$ & $\begin{array}{l}-0.4011 \\
(0.3735)\end{array}$ & $\begin{array}{l}1.4599 \\
(0.2996)\end{array}$ & $\begin{array}{l}-0.1655 \\
(0.6397)\end{array}$ & $\begin{array}{l}0.9673 \\
(0.1608)\end{array}$ & $\begin{array}{l}0.5029 \\
(0.3881)\end{array}$ & $\begin{array}{l}0.3129 * \\
(0.0878)\end{array}$ & $\begin{array}{l}-2.0751^{* * *} \\
(0.0000)\end{array}$ & $\begin{array}{l}0.5297 \\
(0.1174)\end{array}$ \\
\hline Controls & YES & YES & YES & YES & YES & YES & YES & YES & YES & YES & YES & YES \\
\hline Country F.E. & YES & YES & YES & YES & YES & YES & YES & YES & YES & YES & YES & YES \\
\hline adj. R-sq & 0.0949 & 0.1067 & 0.0791 & 0.0950 & 0.0797 & 0.0862 & 0.0132 & 0.0016 & -0.0033 & 0.0011 & 0.0443 & 0.0028 \\
\hline $\mathrm{N}$ & 211 & 211 & 211 & 211 & 211 & 211 & 232 & 232 & 232 & 232 & 232 & 232 \\
\hline
\end{tabular}

Notes: This table presents the baseline model panel estimation results for stock market realised skewness (RS) over the sample period from 2 January 1996 to 13 November 2013 for all 36 countries studied. Model specifications are based on Eq. (5) as follows $R M_{i, t}=\alpha+$ $\beta_{1}$ RM $_{i, t-1}+\beta_{2}$ Rating $_{i, t}+\beta_{3}$ notch $_{w_{i, t}}+\beta_{4}$ Crisis $_{t}+\beta_{5}$ Crisis $_{t} \times$ notch $_{w_{i, t}}+\beta_{6} X_{i, t}+u_{i, t} . \quad R_{t-1}$ is the realized moment (RS) from the past week, Rating is the average linear rating score during the week and notch_w is the cumulative number of notches re-rated during the week. Crisis is either the aggregate financial crisis indicator that takes on a value of one during ALL crisis periods and zero otherwise or during major individual crises. Crisis periods included are from Jul. 1997 - Jan. 1998: the Asian Financial Crisis (AFC); Aug. 1998 - Oct. 1998: the Russian Debt Crisis (RDC); Mar. 2000 - Sept. 2002: the Tech/Terrorist (Tech) crisis of confidence; Jul. 2007 - May 2010: the Global Financial Crisis (GFC); and Dec. 2008 - Nov. 2013: the European Debt crisis (EDC). Country fixed effects and clustered standard errors are used. $*{ }^{* *}$ and $* * *$ denote significance at the 10,5 and $1 \%$ levels (p-values are shown in parentheses). 
Table 9. Impact of sovereign re-ratings on realized kurtosis across major financial crises

\begin{tabular}{|c|c|c|c|c|c|c|c|c|c|c|c|c|}
\hline \multirow[t]{2}{*}{ Dependent var. } & \multicolumn{12}{|c|}{ RK } \\
\hline & \multicolumn{6}{|c|}{ Upgrades } & \multicolumn{6}{|c|}{ Downgrades } \\
\hline Crisis & ALL & AFC & RDC & TECH & EDC & GFC & $\overline{\mathrm{ALL}}$ & AFC & RDC & TECH & EDC & GFC \\
\hline \multirow[t]{2}{*}{ RMt-1 } & 0.1338 & 0.1296 & 0.1300 & 0.1424 & 0.1447 & 0.1463 & $0.2278^{* * *}$ & $0.2328 * * *$ & $0.2390 * * *$ & $0.2445^{* * *}$ & $0.2367 * * *$ & $0.2360^{* * *}$ \\
\hline & $(0.2701)$ & $(0.2653)$ & $(0.2597)$ & $(0.2544)$ & $(0.2449)$ & $(0.2400)$ & $(0.0068)$ & $(0.0088)$ & $(0.0068)$ & $(0.0064)$ & $(0.0066)$ & $(0.0061)$ \\
\hline \multirow[t]{2}{*}{ rating } & 1.3278 & 1.0863 & 1.4012 & 1.4583 & 1.6393 & 1.4841 & 0.1676 & 0.3656 & 0.2857 & 0.4850 & 0.1383 & 0.3006 \\
\hline & $(0.4357)$ & $(0.5243)$ & $(0.4304)$ & $(0.3983)$ & (0.3917) & $(0.3698)$ & $(0.8624)$ & $(0.6912)$ & $(0.7585)$ & $(0.5880)$ & (0.8893) & $(0.7813)$ \\
\hline \multirow[t]{2}{*}{ notch_w } & -1.4991 & -1.5650 & -2.1662 & -1.5286 & -2.1204 & -1.4397 & -2.6882 & -1.0608 & 0.8433 & -1.7821 & 0.7824 & -0.0583 \\
\hline & (0.4637) & $(0.4514)$ & $(0.2313)$ & $(0.4589)$ & $(0.2913)$ & $(0.5034)$ & $(0.1509)$ & $(0.5906)$ & $(0.5903)$ & $(0.3064)$ & $(0.5550)$ & (0.9773) \\
\hline \multirow[t]{2}{*}{ Crisis } & 4.6891 & 59.8267 & 14.3890 & $24.9278^{* *}$ & -1.8720 & -1.2039 & 0.9555 & -3.7410 & 5.5658 & 0.0000 & -1.4487 & 10.6608 \\
\hline & $(0.4742)$ & $(0.2126)$ & $(0.3513)$ & $(0.0001)$ & $(0.8797)$ & $(0.8940)$ & $(0.8954)$ & $(0.7109)$ & $(0.3562)$ & (0.9999) & $(0.8526)$ & (0.4719) \\
\hline \multirow{2}{*}{ Crisis*notch_w } & -0.6238 & -31.3142 & 2.1821 & 0.0000 & 3.9086 & -0.3935 & $7.2514^{*}$ & 6.6605 & -3.9362 & $24.1920 * *$ & -4.2889 & -9.5460 \\
\hline & $(0.9435)$ & (0.1796) & $(0.5136)$ & (0.9999) & (0.4498) & $(0.9610)$ & $(0.0670)$ & $(0.2953)$ & (0.1191) & $(0.0000)$ & $(0.2144)$ & $(0.2719)$ \\
\hline Controls & YES & YES & YES & YES & YES & YES & YES & YES & YES & YES & YES & YES \\
\hline Country F.E. & YES & YES & YES & YES & YES & YES & YES & YES & YES & YES & YES & YES \\
\hline adj. R-sq & 0.0157 & 0.0320 & 0.0277 & 0.0212 & 0.0146 & 0.0127 & 0.0706 & 0.0540 & 0.0603 & 0.1021 & 0.0573 & 0.0577 \\
\hline $\mathrm{N}$ & 211 & 211 & 211 & 211 & 211 & 211 & 232 & 232 & 232 & 232 & 232 & 232 \\
\hline
\end{tabular}

Notes: This table presents the baseline model panel estimation results for stock market realised kurtosis (RK) over the sample period from 2 January 1996 to 13 November 2013 for all 36 countries studied. Model specifications are based on Eq. (5) as follows $R M_{i, t}=\alpha+$ $\beta_{1} R M_{i, t-1}+\beta_{2}$ Rating $_{i, t}+\beta_{3}$ notch $_{w_{i, t}}+\beta_{4}$ Crisis $_{t}+\beta_{5}$ Crisis $_{t} \times$ notch $_{w_{i, t}}+\beta_{6} X_{i, t}+u_{i, t} . \quad R M_{t-1}$ is the realized moment (RK) from the past week, Rating is the average linear rating score during the week and notch_w is the cumulative number of notches re-rated during the week. Crisis is either the aggregate financial crisis indicator that takes on a value of one during ALL crisis periods and zero otherwise or during major individual crises. The crisis periods included are from Jul. 1997 - Jan. 1998: the Asian Financial Crisis (AFC); Aug. 1998 - Oct. 1998: the Russian Debt Crisis (RDC); Mar. 2000 - Sept. 2002: the Tech/Terrorist (Tech) crisis of confidence; Jul. 2007 - May 2010: the Global Financial Crisis (GFC); and Dec. 2008 - Nov. 2013: the European Debt crisis (EDC). Country fixed effects and clustered standard errors are used. $*, * *$ and $* * *$ denote significance at the 10,5 and $1 \%$ levels (p-values are shown in parentheses). 